\title{
Dynamic Effects of Public Investment Support in the Food and Beverage Industries
}

\author{
Jindřich Špička
}

Faculty of Business Administration, University of Economics, Prague, Czech Republic

\begin{abstract}
Impact evaluation of public investment is essential for policy makers to evaluate the effectiveness of public resource allocation and for company management from various industries to determine whether to participate in grant programmes. This article aims to use statistical and econometrical methods (such as propensity score matching, average treatment effect on treated, difference-in-difference approach and pooled regression with time lags) to evaluate the impacts of investment support from the Rural Development Programme, national sources and the Operational Programme Enterprise and Innovation on selected key economic indicators. This representative case study of 412 companies from the Czech food and beverage industry during the period from 2007-2015 noted some interesting findings, many of which go against previous findings. The food and beverage industry is an important beneficiary of public investment subsidies. Investment support increases investment activity and the size of supported companies. This investment support could lead to a crowdingout effect, which has been revealed in recent studies. Simultaneously, investment support changes the capital structure of participants towards higher use of bank loans and positively affects long-term profitability. However, there were not any significant, positive effects on the intensity of the use of fixed assets and labour productivity, which has been a key impact indicator for programme evaluations. However, research revealed positive dynamic effects of investment support on improving resource efficiency.
\end{abstract}

\section{Keywords}

Treatment effects, impact evaluation, lagged effects, food and beverage industry.

Špička, J. (2018) "Dynamic Effects of Public Investment Support in the Food and Beverage Industries", AGRIS on-line Papers in Economics and Informatics, Vol. 10, No. 1, pp. 91-110. ISSN 1804-1930. DOI 10.7160/aol.2018.100108.

\section{Introduction}

Many companies in various industries use investment subsidies from national and international public sources. In the European Union, there are structural funds and development programmes to increase the competitiveness of companies. Each country adds its own national sources to co-finance investment projects or provides full national investment support for enterprises that are not eligible for support from European funds.

There are many stakeholders interested in how such programmes work, including beneficiaries, governmental payment agency, ministry, banks, and the European Commission. Impact evaluation is particularly interesting for public money providers (such as the ministry and European Commission). Public investment support principles are closely linked to concepts of economy, efficiency and effectiveness. Each programme document contains a set of objectives that must be accomplished (effectiveness). Once the goals are attained, it is fundamental to see how they can be met with the least amount of effort (efficiency). Unlike efficiency, which examines the volume of resources and their utilization, economy looks more in terms of their costs. Impact evaluation of public investment support is in the spotlight of researchers and analysts working for the public sector.

Most published studies have been empirical studies regarding the impact evaluation of public investment support. Impact evaluation spans qualitative and quantitative methods, as well as ex ante and ex post methods. (Khandker et al., 2010) provided a good overview of econometric quantitative methods. Variants of impact evaluation include randomized evaluations (Duflo et al., 2008), the propensity score matching (PSM) approach (Caliendo and Kopeinig, 2008), doubledifference (DID) methods (Abadie, 2005; Bertrand et al., 2004; Heckman et al., 1998), the use 
of instrumental variables (Angrist et al., 1996), regressiondiscontinuity(CerquaandPellegrini, 2014; Decramer and Vanormelingen, 2016; Hahn et al., 2001; Lee and Lemieux, 2010; van der Klaauw, 2002) and pipeline comparisons (Ravallion, 2005). The main challenge across different types of quantitative evaluation methods is to find a good comparison point, such as a beneficiary's outcome in the absence of the intervention. However, some authors do not prefer matching before impact evaluation (Petrick and Zier, 2011). The (European Commission - Directorate-General for Agriculture and Rural Development, 2014) presented a broader set of quantitative and qualitative evaluation methods (Table 1).

A comprehensive discussion about the advantages and disadvantages of methods is beyond the scope of this article. This article is about the application of selected statistical and econometric methods to the food processing industry. Thus, an overview of econometric methods is presented in the introduction. The theoretical part of this article compares investigated indicators, methods, regions and results from relevant, recentlypublished articles. Table 2 summarizes key information, and results are discussed later. It is evident that there is not a consensus about methods and indicators. The choice of indicators depends on data availability and the purpose of evaluation.

There have been only a few published studies focused on the food industry, although it is an important beneficiary of European and national funds. In the Czech Republic, companies in the food and beverage industry received 8 billion CZK (i.e., more than 300 million EUR) from 2008-2015. Therefore, it is highly important to evaluate the effects of investment subsidies on key economic indicators.

The selection of key indicators depends on the purpose of the grant programmes. There were three main development programmes for food and beverage industries in the Czech Republic during the previous programming period. First, the Rural Development Programme (RDP) provided investment subsidies for small and medium enterprises within the following two sub-measures: I.1.3.1 Adding value to agricultural and food products, and I.1.3.2 Cooperation for development of new products, processes and technologies (or innovations) in food industry. The measures were granted for tangible and intangible investments concerning processing, marketing and/or development of new products, processes and technologies linked to products, covered by Annex I of the EC Treaty (except for fishery products), and respecting the EC standards applicable to the investment concerned (MoA, 2008). The investments should improve the overall performance of the small and medium enterprises and increase competitiveness

\begin{tabular}{|c|c|c|c|}
\hline Method & Input & Output & Examples of methods \\
\hline Econometric methods & $\begin{array}{l}\text { Economic theory and data } \\
\text { at unit level }\end{array}$ & $\begin{array}{l}\text { Estimates of (net) effects } \\
\text { (cardinal), hypothesis tests }\end{array}$ & PSM, regression analysis, DiD \\
\hline Experimental methods & $\begin{array}{l}\text { Designed experiment } \\
\text { observations }\end{array}$ & $\begin{array}{l}\text { Estimates of (net) effects } \\
\text { (cardinal) hypothesis tests }\end{array}$ & $\begin{array}{l}\text { RCT: Phase in design, pilot } \\
\text { project design, encouragement } \\
\text { design }\end{array}$ \\
\hline $\begin{array}{l}\text { Computational economic } \\
\text { models }\end{array}$ & $\begin{array}{l}\text { Economic theory } \\
\text { and parameters }\end{array}$ & $\begin{array}{l}\text { Estimates of impacts } \\
\text { (cardinal) }\end{array}$ & $\begin{array}{l}\text { Regional and national input- } \\
\text { output, general and partial } \\
\text { equilibrium models, farm models, } \\
\text { CBA, CEA }\end{array}$ \\
\hline Combinations of approaches & All of the above & All of the above & $\begin{array}{l}\text { GRIT, theory of driving forces, } \\
\text { pressures, states, impacts, } \\
\text { responses }\end{array}$ \\
\hline
\end{tabular}

Note: $\mathrm{CBA}=$ Cost-benefit analysis, CEA $=$ Cost-effectiveness analysis, LCA $=$ Life-cycle analyses, GRIT $=$ Generation of Regional Input-Output Tables, MAPP = Method for Impact Assessment of Programmes and Projects, RCT = Randomized controlled trial, SEA = Strategic Environmental Assessment

Source: (European Commission - Directorate-General for Agriculture and Rural Development, 2014)

Table 1: Overview of evaluation approaches. 


\begin{tabular}{|c|c|c|c|c|}
\hline Methods & Source & Region (Time) & Industry & Key Indicators \\
\hline $\begin{array}{l}\text { General method } \\
\text { of moments (GMM) } \\
\text { by (Arellano and Bond, 1998) }\end{array}$ & $\begin{array}{l}\text { Harris and Trainor } \\
(2005)\end{array}$ & $\begin{array}{l}\text { Northern Ireland } \\
\text { (1983-1997) }\end{array}$ & Manufacturing & Total factor productivity (TFP) \\
\hline $\begin{array}{l}\text { Propensity score matching } \\
\text { (PSM) DID estimator (DID) }\end{array}$ & $\begin{array}{l}\text { Bernini and Pellegrini } \\
\text { (2011) }\end{array}$ & $\begin{array}{l}\text { Southern Italy } \\
\text { (1996-2004) }\end{array}$ & Manufacturing & $\begin{array}{l}\text { Output } \\
\text { Employees } \\
\text { Fixed assets } \\
\text { Gross Margin/Output } \\
\text { Profitability (ROI, ROE) } \\
\text { Fin. charges/output } \\
\text { Output/employees } \\
\text { Fin. charges/debt } \\
\text { Value added }\end{array}$ \\
\hline $\begin{array}{l}\text { No matching } \\
\text { "Naïve" regression model } \\
\text { using pooled data (panel data } \\
\text { regression) } \\
\text { Static and dynamic (lagged) } \\
\text { version of DID }\end{array}$ & Petrick and Zier (2011) & $\begin{array}{l}\text { Eastern Germany } \\
(1999-2006)\end{array}$ & $\begin{array}{l}\text { Agriculture, } \\
\text { forestry, fishery }\end{array}$ & $\begin{array}{l}\text { Number of employees } \\
\text { Regional population density } \\
\text { Average yearly wages per employee }\end{array}$ \\
\hline $\begin{array}{l}\text { Generalized propensity score } \\
\text { (GPS) }\end{array}$ & Bia and Mattei (2012) & $\begin{array}{l}\text { Northern Italy } \\
(2000-2003)\end{array}$ & Manufacturing & Employment \\
\hline $\begin{array}{l}\text { Average treatment } \\
\text { on treated (ATT) } \\
\text { and DID } \\
\text { Modified conditional DID } \\
\text { estimator (PSM-DID) }\end{array}$ & Michalek (2012) & $\begin{array}{l}\text { Slovakia } \\
(2002-2005) \\
\text { Germany } \\
(2000-2006)\end{array}$ & Agriculture & $\begin{array}{l}\text { Profit / corrected / extended profit } \\
\text { per farm, per family labour, per fully } \\
\text { employed person } \\
\text { Addition to economic assets } \\
\text { Milk production per farm } \\
\text { Labour productivity } \\
\text { Transfers from farm to household for } \\
\text { living, for building of private assets, } \\
\text { total } \\
\text { Farm total employment }\end{array}$ \\
\hline $\begin{array}{l}\text { Average treatment effect } \\
\text { on treated (ATT) and DID } \\
\text { (Abadie and Imbens, 2006) } \\
\text { Nearest neighbour matching }\end{array}$ & Ratinger et al. (2013) & $\begin{array}{l}\text { Czech Republic } \\
(2007-2010)\end{array}$ & Agriculture & $\begin{array}{l}\text { Total sample: } \\
\text { Gross value added (GVA) } \\
\text { Productivity (GVA/Labour cost)Profit } \\
\text { Bank indebtedness } \\
\text { Investment in fixed assets }\end{array}$ \\
\hline $\begin{array}{l}\text { The PSM estimator of net effects } \\
\text { (Smith and Todd, 2005) } \\
\text { Average treatment effect } \\
\text { on treated (ATT) } \\
\text { Conditional difference } \\
\text { in differences (CDID) method }\end{array}$ & $\begin{array}{l}\text { Bartova and Hornakova } \\
\text { (2016) }\end{array}$ & $\begin{array}{l}\text { Slovakia } \\
(2007-2013)\end{array}$ & Agriculture & $\begin{array}{l}\text { Total factor productivity (TFP) } \\
\text { Gross value added (GVA) } \\
\text { Profit } \\
\text { Assets } \\
\text { Utilized Agricultural Area (UAA) } \\
\text { GVA/UAA, GVA/AWU } \\
\text { Profit/UAA, } \\
\text { Profit/AWU } \\
\text { Assets/UAA, Assets/AWU }\end{array}$ \\
\hline $\begin{array}{l}\text { Direct covariate matching } \\
\text { (Ho et al., 2007) } \\
\text { Propensity score matching } \\
\text { (Rosenbaum and Rubin, 1985) } \\
\text { Greedy pair matching without } \\
\text { replacement (no matches outside } \\
\text { calipers) } \\
\text { Average treatment effect } \\
\text { on treated (ATT) } \\
\text { and DID (Heckman et al., 1998) }\end{array}$ & $\begin{array}{l}\text { Kirchweger et al. } \\
(2015)\end{array}$ & $\begin{array}{l}\text { Austria } \\
(2003-2010)\end{array}$ & Agriculture & $\begin{array}{l}\text { Total livestock units (LU) } \\
\text { Stocking density (LU/ha) } \\
\text { Total output } \\
\text { Farm income } \\
\text { Share of net worth on total assets }(\%)\end{array}$ \\
\hline $\begin{array}{l}\text { Regression discontinuity design } \\
\text { (RDD) } \\
\text { by (Lee and Lemieux, 2010) }\end{array}$ & $\begin{array}{l}\text { Decramer and } \\
\text { Vanormelingen (2016) }\end{array}$ & $\begin{array}{l}\text { Belgium } \\
(2001-2012)\end{array}$ & $\begin{array}{l}\text { Multiple } \\
\text { sectors (12) }\end{array}$ & $\begin{array}{l}\text { Fixed assets } \\
\text { Sales } \\
\text { Value added } \\
\text { Employment }\end{array}$ \\
\hline $\begin{array}{l}\text { No matching } \\
\text { Fixed-effect model (panel data } \\
\text { regression) }\end{array}$ & $\begin{array}{l}\text { Naglova et al. (2016); } \\
\text { Spicka et al. (2017) }\end{array}$ & $\begin{array}{l}\text { Czech Republic } \\
(2008-2013)\end{array}$ & $\begin{array}{l}\text { Dairy industry } \\
\text { Meat } \\
\text { processing } \\
\text { industry }\end{array}$ & $\begin{array}{l}\text { Labour productivity } \\
\text { Profitability (ROA) } \\
\text { Capital structure (Credit Debt Ratio) } \\
\text { Production consumption } \\
\text { Sales }\end{array}$ \\
\hline
\end{tabular}


of the agri-food industry. The key economic indicator for impact evaluation was labour productivity (gross value added per worker). In the RDP, sub-measure I.1.3.2 Cooperation for development of new products, processes and technologies (or innovations) in the food industry was also available to large companies. Second, the national support programme of the Ministry of Agriculture No. 13 was complementary to RDP, and it was available to large companies but was not aimed at cooperation projects supported by the RDP (I.1.3.2). Finally, companies making products not covered by Annex I to the EC Treaty were supported by the Ministry of Industry and Trade under the Operational Programme Enterprise and Innovation (MoIT, 2007). Value added was a key performance indicator.

Following the literature review and impact indicators of development and operational programmes, we identified key economic variables that could be affected by investment support. The aim of this article is to ex-post evaluate effects of investment support on the fixed assets, capital structure, labour productivity, profitability and direct cost efficiency of Czech companies producing food and beverages from 2007-2015. Although the impact evaluation that is presented is a case study of the Czech Republic, the methodical framework could be used by other evaluators in different industries and countries.

Labour productivity is an important indicator focused on by the European Commission (European Commission - Directorate-General for Agriculture and Rural Development, 2016), since it is the key economic indicator of a company's productivity (Rezbova and Skubna, 2013). Investment support should increase labour productivity because of the investment in more modern and efficient technology. Moreover, investment support should also focus on creating new jobs and improving the quality of life. However, output should increase more than labour costs (Decramer and Vanormelingen, 2016). The hypothesis is that there is a positive dynamic effect of investment support on labour productivity. Otherwise, the strategic goals of development and operating programmes will not be accomplished. Lagged effects are possible since investments are gradually introduced after completion.

As a consequence of higher investment activity, supported companies should increase fixed assets more dynamically than nonparticipants (Medonos et al., 2012). This hypothesis could be supported by the fact that most investment subsidies should be aimed at improving the value of capital for supported companies. Simultaneously, fixed assets should be used more efficiently, as measured by Fixed Assets Turnover ${ }^{1}$.

The capital structure of supported companies should change as companies use bank loans for financial modernization. If we assume that supported companies have higher investment activity than non-supported companies, there should be significant differences in the credit debt ratio $^{2}$ for participants and nonparticipants (Ratinger et al., 2013). Nevertheless, measuring this dynamic effect could be problematic since taking a bank loan precedes receiving support.

Profitability is an essential indicator of a company's financial performance. There should be a positive effect of investment support on a company's profitability since profitability has been a strategic interest of shareholders (Naglova et al., 2016). Long-term profitability ${ }^{3}$ is a better measure than current profitability, since long-term profitability takes account of retained earnings and is one of the selection criteria for the Czech RDP (MoA, 2008).

Finally, direct cost efficiency ${ }^{4}$ measures a company's operating efficiency. Investment support aims increasing output and decreasing average costs (e.g. energy-saving technologies, lower material losses). There should be positive effects for investment support on direct cost efficiency (European Commission - DirectorateGeneral for Agriculture and Rural Development, 2016).

\section{Materials and methods}

This research is based on the individual data from companies that received investment support from the Ministry of Agriculture and Ministry of Industry and Trade of the Czech Republic in the previous programming period (from 2007 to 2015 when the last applications were completed). The database of supported companies was connected to the financial statement database MagnusWeb, which contains individual data on assets, liabilities, revenues and costs for the companies listed in the Czech Business Register.

\footnotetext{
${ }^{1}$ Fixed Assets Turnover $(\mathrm{x})=$ Sales $/$ Fixed Assets

${ }^{2}$ Credit Debt Ratio (\%) $=($ Bank Loans $/$ Total Assets $) \times 100$

${ }^{3}$ Long-term Profitability $(\%)=($ Retained Profit + Current Profit $) /$ Total Assets x 100

${ }^{4}$ Direct Cost Efficiency $=$ Cost of Material, Energy and Services $/$ Sales
} 
Ex post impact evaluation of public investment support often follows a DID framework. Compared with PSM, DID assumes that unobserved heterogeneity in participation is present but such factors are time invariant. The literature recommends combining the PSM and DID to resolve the problem of selection bias by matching units (Khandker et al., 2010). It is necessary to process the PSM followed by the DID estimate. This approach is called conditional DID and it has been used for impact evaluation (Bartova and Hornakova, 2016; Bergemann et al., 2009; Gilligan and Hoddinott, 2007; Kirchweger and Kantelhardt, 2015; Pufahl and Weiss, 2009).

Propensity score matching is the most common matching technique used in the evaluation of grant programmes. PSM constructs a statistical comparison group that is based on a model of the probability of treatment participation by using observed characteristics. Participants are then matched on the basis of this probability, called a propensity score, to nonparticipants (Khandker et al., 2010). There are two assumptions for PSM validity as follows: i) conditional independence (namely, that unobserved factors do not affect participation), and ii) sizable, common support or overlap in propensity scores across the participant and nonparticipant samples. In this article, the PSM process follows four main steps (European Commission - Directorate-General for Agriculture and Rural Development, 2014; Khandker et al., 2010).

1. Build a dataset that includes participants and nonparticipants from the time periods prior to and following investment support. This dataset is characterized in a separate chapter. Ideally, the sample should respect the population structure. The sample size was calculated through the same method as (Krejcie and Morgan, 1970).

$s=\frac{X^{2} N P(1-P)}{d^{2}(N-1)}+X^{2} P(1-P)$,

where $s$ denotes the required sample size, $X^{2}$ indicates the Chi-squared table value for 1 degree of freedom at the desired confidence level (3.841), $P$ represents the population proportion (assumed to be 0.5 since this would provide the maximum sample size) and $d$ denotes the statistical significance expressed as a proportion (0.05).

There were 6560 Czech companies producing food and beverages (NACE 10 and 11) at the beginning of the programming period in 2007. Equation (1) resulted in a required sample size of 363 companies. We gathered 620 randomly selected companies, which is higher than expected. A Chi-squared test was performed to guarantee that the actual set of companies does not significantly differ from the structure of NACE 10 and 11 (4-digit codes).

2. Select performance and structural variables (covariates) to find similar groups of participants and nonparticipants. Generally, covariates entering the logit function are expected to determine both programme participation and outcomes. The selection of covariates was processed through principal component analysis (PCA).

The PCA identified 13 variables, representing $80.69 \%$ of the variability of the original 63 variables. However, in the logit regression, we did not directly use the factors, but we used the indicators that had a high correlation with the factors, since they were most suitable for analysis. Annex table A1 shows the set of selected indicators and the factors' focus. It is obvious that factors cover the most important structural and economic features of companies.

3. Calculate propensity scores for each individual unit based on the likely determinants of a company's participation in the modernization programme. The logit model estimates participation probabilities for companies that received an investment subsidy ("participants", $T=1$ ) and those without any investment support in the reference period ("nonparticipants", $T=0$ ). In this case, causality is not as interesting as the correlation of covariates with $T$. There are three significant determinants of a company's participation, including the amount of bank loans, liquidity (Acid Test Ratio) and capital structure (Debt Ratio), which were used as covariates for propensity score matching. Other variables did not significantly determine participation in the modernization programme. The distribution of estimated propensity scores is illustrated in Figure 1, where a good overlap is evident. Annex table A2 provides the results of logit analysis. 


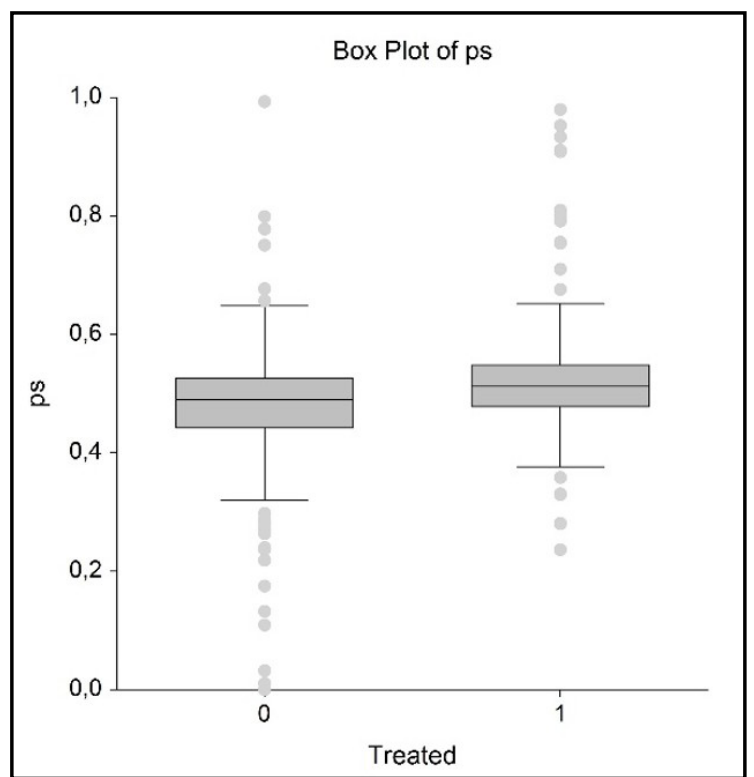

Source: own calculation

Figure 1. Distribution of propensity scores of participation (logit model).

4. Matching algorithms are used to match participants to nonparticipants. Approaches used for matching include nearest-neighbour matching, caliper and radius matching, stratification and interval matching, and kernel and local linear matching. Nearestneighbour matching was selected since it has been the most commonly used matching framework in empirical studies of the agrifood sector. The nearest-neighbour was matched to the estimated propensity score $p(X)$ as an aggregate measurement. Probability $p(X)$ was estimated on the fitted values with a parametric logit model, using the observed treatment assignment (yes/no) as the explained and $X$ as the explanatory variables. When performing an impact evaluation on agroup of companies with different branches, it was necessary to acknowledge that participants and nonparticipants have similar branch structures classified by NACE (4-digit) codes since the food and beverage industry has very high heterogeneity.

Two distinct matching procedures can be applied - optimal data matching (ODM) and greedy data matching (GDM). The linear greedy data matching algorithm was applied in the article, such as in previous studies of the agri-food sector by other authors (Bozik, 2011; Kirchweger et al., 2015). There are several ways to measure distance. The best distance measure depends on the number of covariate variables, the variability within the covariate variables, and other factors. Based on empirical studies that compared various distance metrics (Gu and Rosenbaum, 1993; Rosenbaum, 1989; Rosenbaum and Rubin, 1985), authors decided to use the Mahalanobis Distance within Propensity Score Calipers (no matches outside calipers) as this paper's distance calculation method since it is best when there are fewer covariates (3) to match.

The performance of distance metrics involving calipers is somewhat dependent on the caliper radius used. The level of caliper radius depends on how much tight or loose matching is preferred. The caliper radius is calculated using sample variances of the treatment and control groups. Because of the limited available data, "loose matching" with $1 \sigma$ was applied. The Mahalanobis distance within propensity score calipers (no matches outside calipers) can be formulated as

$$
\begin{aligned}
d(i, j) & =\left\{\begin{array}{c}
\left(\mathbf{u}_{i}-\mathbf{u}_{j}\right)^{T} C^{-1}\left(\mathbf{u}_{i}-\mathbf{u}_{j}\right)|i f| q\left(\mathbf{x}_{i}\right)-q\left(\mathbf{x}_{j}\right) \mid \\
\infty
\end{array}\right. \\
& \left.\leq c \text { and } F M_{i, l}=F M_{j, l} \text { for all } l\right\} \\
& \text { otherwise }
\end{aligned}
$$

where $i$ refers to the $i^{\text {th }}$ treatment subject, $j$ refers to the $j^{\text {th }}$ control subject, $d(i, j)$ is the estimated distance between subjects $i$ and $j, \mathbf{x}$ is the vector of observed covariates used to estimate the propensity score, and $q(\mathbf{x})$ is the propensity score based on the covariates $\mathbf{x}$. Vector $\mathbf{u}=(\mathbf{y}, q(\mathbf{x}))$ is the vector of observed covariates $\mathbf{y}$ and the propensity score, $\mathrm{C}$ is the sample covariance matrix of the matching variables (including the propensity score) from the full set of control subjects, and $\mathrm{c}$ is the caliper radius. $F M_{i, l}=F M_{j, l}$ are the values of the $l^{\text {th }}$ forced match variable for subjects $i$ and $j$, respectively. If no forced match variables are specified, then $F M_{i, l}=F M_{j, l}$ for all $l$. However, we used one forced match variable 4-digit NACE code to have the same branch structure in groups of participants and nonparticipants. The number of matches per treatment was 1 (i.e., 1:1 matching), as there were not enough nonparticipants for $1: \mathrm{N}$ matching.

Finally, we selected the matching order to be sorted by distance. This option caused the programme to sort the matrix of all pair-wise treatment-control distances. It then assigned matches in ascending order starting with the smallest distance until all treatments have been matched with the specified number of controls. Annex table A3 shows the results of matching.

The final sample includes 206 participants and 206 nonparticipants from the same branch 
of the food and beverages industry. Some participants (23.99\%) and nonparticipants (40.97 $\%$ ) were not matched because of the specified forced match variable's 4-digit NACE and caliper radius.

5. Calculate average treatment effects. The European Commission (European Commission - Directorate-General for Agriculture and Rural Development, 2016) recommends using the average treatment effects on treated (ATT) for evaluating the effects of investment support. ATT is defined as

$\tau \mathrm{ATT}=\mathrm{E}[\tau \mid \mathrm{D}=1]=\mathrm{E}[\mathrm{Y}(1) \mid \mathrm{D}=1]-\mathrm{E}[\mathrm{Y}(0) \mid \mathrm{D}=1]$

where $\tau=\mathrm{Y}(1)-\mathrm{Y}(0)$. $\mathrm{Y}(\mathrm{D})$ is a result variable where D equals 1 if the unit received investment support (participant) and 0 otherwise (nonparticipant).The theoretical principle of ATT can be described through the Roy-Rubin-model (Caliendo and Kopeinig, 2008). A positive (negative) ATT indicates a better (worse) development of outcome variables for treated companies when compared to control companies.

We calculated the difference-in-difference effects (DID) of indicators from 2007-2015. We estimated DID cumulatively in each year between participants and nonparticipants. The starting point was 2007 at the beginning of the programming period. Then, differences between 2007 and subsequent years were tested.

To measure the dynamic effects of investment subsidies, robust linear dynamic panel-data estimation was applied based on OLS (Allison, 2009; Wooldridge, 2016). The evaluation of the model included a Wald test of simple and composite linear hypotheses about the parameters of the fit model (Greene, 2012). Since the panel data have both a time-series and cross-sectional dimension, we used robust estimation assuming there are heteroscedastic and autocorrelated errors. The fixed-effects were estimated as a panel regression between the economic indicator $(y)$ and investment subsidies $(x)$.

$y_{i t}=\alpha+x_{i t} \beta+v_{i}+\epsilon_{i t} \quad i=1, \ldots, N ; t=1, \ldots, T$,

where $y_{i t}$ is an observation of a dependent variable (labour productivity ${ }^{5}$, fixed assets, fixed assets

\footnotetext{
${ }^{5}$ Labour Productivity $=$ Value Added $/$ Total Personnel Expenses
}

turnover ${ }^{6}$, credit debt ratio $^{7}$, long-term profitability ${ }^{8}$, direct cost efficiency ${ }^{9}$ ) for $\mathrm{i}$-th unit in time $t$. $\alpha$ is a scalar common to all entities. $x_{i t}$ is it-th row of NT $\times$ K matrix X, which contains the observed values of $\mathrm{K}$. It denotes whether the company was supported ( 0 if company was not supported, 1 if company received support). Therefore, the model with binary regressors estimates the average impact of the investment subsidy on the selected economic indicator. $v_{i}$ is the unitspecific error term. It differs between units, but for any particular unit its value is constant. $\epsilon_{i t}$ is the "usual" error term with the typical properties (mean 0, uncorrelated with itself, uncorrelated with $x$, uncorrelated with $v$, and homoskedastic), although with more research we could decompose $\epsilon_{i t}=u_{t}+\omega_{i t}$, assume that $\omega_{i t}$ is a conventional error term, and better describe $u_{t}$.

We tested one-year and two-year ${ }^{10}$ lags of independent variables, since we aimed to reveal some effects of an investment subsidy one year after project was finished and launched. The dynamic panel-data estimation was applied in the sample of 412 companies (206 participants and 206 nonparticipants) to respect matching results and the counterfactual approach. Linear panel-data estimation and diagnostic tests were processed by the STATA software package.

\section{Results and discussion}

Heterogeneity among firms and sectors is an important feature of the Czech food processing industry (Rudinskaya, 2017). Drawing investment subsidies from the RDP is the domain of small and medium enterprises. In the sample of 206 participants, 215 projects were supported from the RDP, 124 projects from national subsidy programme and 137 projects from the Operation Programme of the Ministry of Industry and Trade from 2008-2015. Table 3 shows that this sample amply represents the total number of supported projects.

Before we start to describe the results of evaluation, it would be interesting to look at the significance of investment support on the supported companies. Figure 2 presents the share of investment support

\footnotetext{
${ }^{6}$ Fixed Assets Turnover $(\mathrm{x})=$ Sales $/$ Fixed Assets

${ }^{7}$ Credit Debt Ratio (\%) = (Bank Loans / Total Assets) $x 100$

${ }^{8}$ Long-term Profitability $(\%)=($ Retained Profit + Current Profit $) /$ Total Assets x 100

${ }^{9}$ Direct Cost Efficiency $=$ Cost of Material, Energy and Services $/$ Sales ${ }_{10}$ Two-year lag was processed when we supposed delayed effect as a consequence of running up the investment (fixed assets turnover, long-term profitability, labour productivity, direct cost efficiency).
} 


\begin{tabular}{|l|l|l|l|}
\hline Size & RDP & National subsidy from Ministry of Agriculture & Ministry of Industry and Trade \\
\hline Small & $86(265913942)$ & 0 & $41(114543000)$ \\
\hline Medium & $113(493782253)$ & 0 & $96(554470600)$ \\
\hline Large & $16(109794481)$ & $124(393116401)$ & 0 \\
\hline Total sample & $215(869490676)$ & $124(393116401)$ & $137(744765600)$ \\
\hline \% of population & $18.84(21.72)$ & $40.52(30.35)$ & $32.08(27.13)$ \\
\hline
\end{tabular}

Note: number of projects (investment subsidy in CZK)

Source: own calculation

Table 3: Distribution of participants in the sample (2008-2015).

in total assets of the supported companies (in the year of receiving the subsidy).

We found that $80 \%$ of projects had less than a $5 \%$ share of investment subsidies in the total assets. However, the project might be relatively large if we consider that approximately $10 \%$ is the depreciation rate under the assumption of a 10-year average economic life of the projects.

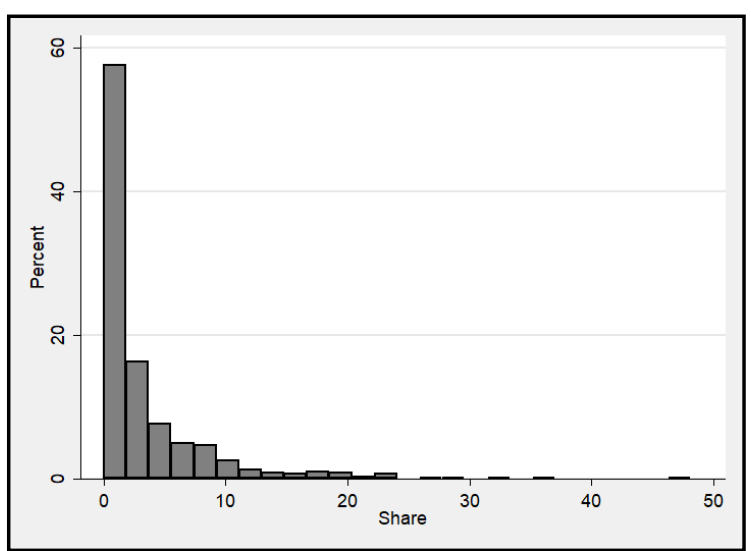

Source: own calculation

Figure 2. Share of investment subsidies in total assets of participants.

\section{Average treatment effect, DID and lagged effects}

Change in the fixed assets was evaluated as first (Table 4).

It is evident that ATT was increasing as average fixed assets of participants increased from $72.65 \mathrm{~m} \mathrm{CZK}$ to $113.25 \mathrm{~m} \mathrm{CZK}$ from 2007-15. Simultaneously, average fixed assets of nonparticipants were relatively stagnant. ATT became statistically significant in 2012 at a 0.05 significance level. This finding is in compliance with other authors (Decramer and Vanormelingen, 2016; Kirchweger and Kantelhardt, 2015). While participants invested in upgrading and expanding production capacities (Spicka et al., 2016), the non-participants invested enough to cover the depreciation of fixed assets.

The DID showed clearly positive cumulative effects of investment support on fixed assets when compared to the base year 2007. However, linear panel-data estimation showed significant effects without any lags, but there were not any significant lagged effects. This can be explained by the fact that companies book new fixed assets just after they complete projects. Investment subsidies increased the value of fixed assets by an average of 10.51 million CZK ( $p$-value $=0.034)$. Overall, it can be concluded that investment support positively affects investment in fixed assets. Alternatively, nonparticipants could be crowded out because they did not expand. A recent study showed that the crowding-out effect of the RDP is close to $100 \%$, implying that firms use public support to substitute for private investments (Ciaian et al., 2015).

Fixed assets turnover measures whether there were any positive effects of investment subsidy on fixed assets efficiency (Table 5) to improve competitiveness and profitability.

Lower participants' turnover of fixed assets since 2010 could be caused by an increase in their profit margins after support when companies started to produce food and beverages with a higher value added. There were not any significant difference-indifference (DID) effects when compared to 2007. However, linear panel-data regression revealed a significant effect without any lags. Coefficients show that investment support decreased fixed asset turnover by an average of 5.322. This is quite logical since investors increased fixed assets, but investment increased without a corresponding increase in sales. After one year of operation, a negative (but not significant) effect on fixed assets turnover continued. When considering a two-year lag, there is a positive but not significant effect of investment support on fixed assets turnover. Thus, an increase in fixed assets turnover is delayed when compared to an increase in fixed assets. However, the positive effect was not significant. It is an important finding for policy makers and management that investment support both increases the value of fixed assets and improves efficiency, but not before two years after launching the finished project on average. Unfortunately, other 


\begin{tabular}{|c|c|c|c|c|c|c|}
\hline Year & Participants & Control & ATT & SE & $\mathrm{t}$ & $\mathrm{p}$-value \\
\hline 2007 & 72653 & 59137 & 13516 & 17964 & 0.7524 & 0.4522 \\
\hline 2008 & 78699 & 59503 & 19196 & 18258 & 1.0514 & 0.2937 \\
\hline 2009 & 84898 & 59080 & 25818 & 19900 & 1.2974 & 0.1952 \\
\hline 2010 & 90869 & 58314 & 32555 & 20009 & 1.6270 & 0.1045 \\
\hline 2011 & 95041 & 58110 & 36931 & 20239 & 1.8248 & 0.0688 \\
\hline 2012 & 100174 & 58899 & 41274 & 20796 & 1.9847 & 0.0478 \\
\hline 2013 & 103236 & 59405 & 43831 & 20858 & 2.1014 & 0.0362 \\
\hline 2014 & 106187 & 60096 & 46091 & 20712 & 2.2253 & 0.0266 \\
\hline 2015 & 113250 & 59996 & 53254 & 21365 & 2.4925 & 0.0131 \\
\hline DID & Participants & Control & ATT & SE & $\mathrm{t}$ & $\mathrm{p}$-value \\
\hline 2008-07 & 6046 & 366 & 5680 & 1861 & 3.0524 & 0.0024 \\
\hline 2009-07 & 12245 & -57 & 12302 & 4550 & 2.7036 & 0.0071 \\
\hline 2010-07 & 18216 & -823 & 19039 & 5588 & 3.4073 & 0.0007 \\
\hline 2011-07 & 22387 & -1027 & 23414 & 6196 & 3.7790 & 0.0002 \\
\hline 2012-07 & 27520 & -238 & 27758 & 7304 & 3.8005 & 0.0002 \\
\hline 2013-07 & 30582 & 268 & 30315 & 8208 & 3.6934 & 0.0003 \\
\hline 2014-07 & 33533 & 959 & 32574 & 9651 & 3.3754 & 0.0008 \\
\hline 2015-07 & 40597 & 860 & 39737 & 11538 & 3.4442 & 0.0006 \\
\hline OLS & Coef. & Robust SE & $\mathrm{t}$ & p-value & $95 \%$ Conf & . Interval \\
\hline Const. & 75209.7 & 620.5 & 121.21 & 0.000 & 73989.9 & 76429.5 \\
\hline Lag0 & 10508.8 & 4937.4 & 2.13 & 0.034 & 803.1 & 20214.6 \\
\hline Const. & 77886.4 & 392.8 & 198.28 & 0.000 & 77114.3 & 78658.6 \\
\hline Lag1 & -235.2 & 3471.0 & -0.07 & 0.946 & -7058.4 & 6587.9 \\
\hline Wald test & $\mathrm{F}$ & $\mathrm{p}$-value & corr(ui, Xb) & sigma_u & sigma_e & rho \\
\hline Lag0 & 4.53 & 0.034 & 0.099 & 198836.5 & 46994.6 & 0.947 \\
\hline Lag1 & 0.00 & 0.946 & -0.116 & 202354.0 & 44675.5 & 0.954 \\
\hline
\end{tabular}

Source: own calculation

Table 4: ATT, DID and OLS of fixed assets ('000 CZK).

\begin{tabular}{|r|r|r|r|r|r|r|}
\hline \multicolumn{1}{|l|}{ Year } & \multicolumn{1}{l|}{ Participants } & \multicolumn{1}{l|}{ Control } & ATT & SE & p value \\
\hline 2007 & 17.584 & 18.066 & -0.482 & 5.172 & -0.0933 & 0.9257 \\
\hline 2008 & 13.295 & 16.553 & -3.258 & 3.947 & -0.8255 & 0.4096 \\
\hline 2009 & 21.920 & 14.787 & 7.133 & 13.852 & 0.5149 & 0.6069 \\
\hline 2010 & 7.803 & 15.213 & -7.410 & 2.766 & -2.6786 & 0.0077 \\
\hline 2011 & 8.967 & 14.997 & -6.030 & 3.064 & -1.9679 & 0.0498 \\
\hline 2012 & 8.932 & 14.593 & -5.661 & 2.939 & -1.9260 & 0.0548 \\
\hline 2013 & 8.562 & 14.363 & -5.800 & 3.067 & -1.8915 & 0.0593 \\
\hline 2014 & 7.604 & 13.146 & -5.542 & 2.358 & -2.3505 & 0.0192 \\
\hline 2015 & 9.184 & 13.454 & -4.270 & 3.181 & -1.3424 & 0.1802 \\
\hline & Participants & Control & & ATT & & $\mathrm{p}$-value \\
\hline $2008-07$ & -4.204 & -1.425 & -2.778 & 4.161 & -0.6678 & 0.5047 \\
\hline $2009-07$ & 4.422 & -3.191 & 7.613 & 13.384 & 0.5688 & 0.5698 \\
\hline $2010-07$ & -9.695 & -2.765 & -6.930 & 5.134 & -1.3498 & 0.1778 \\
\hline $2011-07$ & -8.531 & -3.054 & -5.477 & 5.025 & -1.0899 & 0.2764 \\
\hline $2012-07$ & -8.566 & -3.456 & -5.110 & 4.838 & -1.0561 & 0.2916 \\
\hline $2013-07$ & -8.936 & -3.616 & -5.320 & 5.304 & -1.0032 & 0.3164 \\
\hline $2014-07$ & -9.895 & -4.833 & -5.062 & 5.220 & -0.9698 & 0.3327 \\
\hline $2015-07$ & -8.314 & -4.524 & -3.790 & 5.630 & -0.6733 & 0.5012 \\
\hline
\end{tabular}

Source: own calculation

Table 5: ATT, DID and OLS of fixed assets turnover (x) (to be continued) 
Dynamic Effects of Public Investment Support in the Food and Beverage Industries

\begin{tabular}{|c|c|c|c|c|c|c|}
\hline OLS & Coef. & Robust SE & $\mathrm{t}$ & $\mathrm{p}$-value & $95 \%$ Cor & f. Interval \\
\hline Const. & 13.945 & 0.225 & 61.910 & 0.000 & 13.502 & 14.388 \\
\hline Lag0 & -5.322 & 1.790 & -2.970 & 0.003 & -8.841 & -1.803 \\
\hline Const. & 12.810 & 0.063 & 203.800 & 0.000 & 12.687 & 12.934 \\
\hline Lag1 & -0.891 & 0.555 & -1.600 & 0.109 & -1.982 & 0.201 \\
\hline Const. & 12.297 & 0.200 & 61.410 & 0.000 & 11.903 & 12.691 \\
\hline Lag2 & 0.846 & 1.765 & 0.480 & 0.632 & -2.623 & 4.316 \\
\hline Wald test & $\mathrm{F}$ & p-value & $\operatorname{corr}(u i, \mathrm{Xb})$ & sigma_u & sigma_e & rho \\
\hline Lag0 & 8.840 & 0.003 & 0.030 & 29.803 & 51.641 & 0.250 \\
\hline Lag1 & 2.570 & 0.109 & 0.058 & 30.013 & 52.644 & 0.245 \\
\hline Lag2 & 0.230 & 0.632 & -0.061 & 30.331 & 55.642 & 0.229 \\
\hline
\end{tabular}

Source: own calculation

Table 5: ATT, DID and OLS of fixed assets turnover (x) (continuation).

authors have not yet used fixed assets turnover. However, we found that fixed assets turnover is an important indicator for the impact evaluation of investment support.

Credit debt ratio measures whether there are any differences in the use of bank loans for investment activity between participants and nonparticipants (table 6).

Participants had higher credit debt ratios from 2007-2015. Differences between participants and the control group were statistically significant at the 0.05 significance level since 2009. This indicates that participants used more bank loans for co-financing investment projects. However, there were not any difference-indifference effects. Companies in the control group slightly decreased their credit debt ratio, while indicators in the participant group fluctuated. A higher credit debt ratio for participants corresponds to findings of other authors (Ratinger et al., 2013) but DID effects go against them. However, linear panel-data analysis established a significant impact for investment support on changing credit debt ratios. This finding indicates that supported companies used bank loans for co-financing fixed asset increases. However, recent empirical research showed a negative impact for long- and short-term debt on the technical efficiency of the Czech food processing industry (Rudinskaya, 2017). Investment support increased credit debt ratio by 2.554 p.p. in the year of support. Measuring dynamic effects could be slightly biased for large projects when taking a bank loan precedes getting support by one or more years. Usually, companies take bank loans before starting their investment projects. After the project is completed, companies get the investment subsidy. Nevertheless, there is no bias in the case of smaller projects (which prevail) when getting support often quickly follows taking a bank loan.

Table 7 presents the effects of investment support on long-term profitability including linear paneldata estimates.

Long-term profitability follows both current and retained earnings. It is one of the key selection criteria for the evaluation of applicants when projects are submitted in the Czech Republic. Therefore, it is evident that participants had higher long-term profitability for 2007-2015, and that it was significantly different at the 0.05 level in most years. However, positive DID effects of investment support on long-term profitability were not significant for the whole period. There were two years (2009 and 2010) with significant dynamic effects at the 0.05 significance level when long-term profitability of participants sharply increased, unlike the control group where the indicator dropped against 2007. There was the deep economic crisis in 2009 and 2010. The long-term profitability of the nonparticipant group decreased, while the profitability of participants increased. However, participants reinvested earnings and thus increased retained earnings. There were also positive significant effects of investment support on long-term profitability at the 0.1 level for the years 2012, 2014, and 2015 when compared to 2007.

Concerning dynamic effects, there were not any significant effects for investment support on long-term profitability at the 0.05 significance level. However, there were significant positive effects at the 0.1 significance level in the year of support $(b=1.690, p$-value $=0.084)$ and two years after support $(b=1.540, p$-value $=0.053)$. The $p$-value of effects two years after support is very close to 0.05 . Other authors did not use long-term profitability but instead used current profitability 


\begin{tabular}{|c|c|c|c|c|c|c|}
\hline Year & Participants & Control & ATT & $\mathrm{SE}$ & $\mathrm{t}$ & $\mathrm{p}$-value \\
\hline 2007 & 14.580 & 12.531 & 2.049 & 1.615 & 1.2686 & 0.2053 \\
\hline 2008 & 15.577 & 13.194 & 2.383 & 1.621 & 1.4704 & 0.1422 \\
\hline 2009 & 14.570 & 11.341 & 3.228 & 1.490 & 2.1673 & 0.0308 \\
\hline 2010 & 13.867 & 10.599 & 3.268 & 1.430 & 2.2858 & 0.0228 \\
\hline 2011 & 14.686 & 10.830 & 3.856 & 1.420 & 2.7149 & 0.0069 \\
\hline 2012 & 14.900 & 10.313 & 4.587 & 1.400 & 3.2761 & 0.0011 \\
\hline 2013 & 13.847 & 10.212 & 3.635 & 1.343 & 2.7062 & 0.0071 \\
\hline 2014 & 14.029 & 9.875 & 4.153 & 1.382 & 3.0059 & 0.0028 \\
\hline 2015 & 14.817 & 10.059 & 4.758 & 1.424 & 3.3416 & 0.0009 \\
\hline DID & Participants & Control & ATT & SE & $t$ & p-value \\
\hline $2008-07$ & 0.997 & 0.663 & 0.334 & 0.928 & 0.3597 & 0.7193 \\
\hline 2009-07 & -0.010 & -1.190 & 1.179 & 1.090 & 1.0824 & 0.2797 \\
\hline $2010-07$ & -0.713 & -1.932 & 1.219 & 1.180 & 1.0335 & 0.3020 \\
\hline 2011-07 & 0.106 & -1.701 & 1.807 & 1.305 & 1.3847 & 0.1669 \\
\hline 2012-07 & 0.320 & -2.218 & 2.538 & 1.369 & 1.8537 & 0.0645 \\
\hline 2013-07 & -0.733 & -2.319 & 1.586 & 1.357 & 1.1687 & 0.2432 \\
\hline 2014-07 & -0.551 & -2.655 & 2.104 & 1.483 & 1.4191 & 0.1566 \\
\hline 2015-07 & 0.237 & -2.472 & 2.709 & 1.479 & 1.8317 & 0.0677 \\
\hline OLS & Coef. & Robust SE & $\mathrm{t}$ & p-value & $95 \%$ Con & Interval \\
\hline Const. & 12.447 & 0.073 & 169.960 & 0.000 & 12.303 & 12.591 \\
\hline Lag0 & 2.554 & 0.583 & 4.380 & 0.000 & 1.409 & 3.700 \\
\hline Const. & 12.542 & 0.058 & 217.850 & 0.000 & 12.428 & 12.655 \\
\hline Lag1 & 1.131 & 0.509 & 2.220 & 0.027 & 0.131 & 2.131 \\
\hline Wald test & $\mathrm{F}$ & p-value & corr(ui, Xb) & sigma_u & sigma_e & rho \\
\hline Lag0 & 19.210 & 0.000 & 0.035 & 12.787 & 8.090 & 0.714 \\
\hline Lag1 & 4.950 & 0.027 & 0.041 & 12.812 & 7.760 & 0.732 \\
\hline
\end{tabular}

Source: own calculation

Table 6: ATT, DID and OLS of credit debt ratio (\%).

\begin{tabular}{|c|c|c|c|c|c|c|}
\hline Year & Participants & Control & ATT & $\mathrm{SE}$ & $\mathrm{t}$ & $p$-value \\
\hline 2007 & 18.799 & 15.272 & 3.528 & 3.545 & 0.9950 & 0.3203 \\
\hline 2008 & 19.884 & 14.341 & 5.544 & 3.854 & 1.4383 & 0.1511 \\
\hline 2009 & 22.643 & 13.203 & 9.440 & 4.530 & 2.0837 & 0.0378 \\
\hline 2010 & 23.141 & 13.963 & 9.178 & 4.550 & 2.0172 & 0.0443 \\
\hline 2011 & 22.702 & 14.075 & 8.628 & 5.079 & 1.6985 & 0.0902 \\
\hline 2012 & 22.492 & 10.606 & 11.886 & 5.699 & 2.0856 & 0.0376 \\
\hline 2013 & 23.125 & 11.142 & 11.983 & 6.179 & 1.9393 & 0.0532 \\
\hline 2014 & 25.637 & 10.008 & 15.629 & 7.454 & 2.0967 & 0.0366 \\
\hline 2015 & 26.610 & 11.933 & 14.677 & 7.242 & 2.0267 & 0.0433 \\
\hline DID & Participants & Control & ATT & SE & $\mathrm{t}$ & $p$-value \\
\hline 2008-07 & 1.085 & -0.931 & 2.016 & 1.452 & 1.3878 & 0.1659 \\
\hline 2009-07 & 3.843 & -2.068 & 5.912 & 2.317 & 2.5512 & 0.0111 \\
\hline 2010-07 & 4.342 & -1.308 & 5.650 & 2.687 & 2.1023 & 0.0361 \\
\hline 2011-07 & 3.903 & -1.197 & 5.100 & 3.706 & 1.3759 & 0.1696 \\
\hline 2012-07 & 3.693 & -4.665 & 8.358 & 4.507 & 1.8545 & 0.0644 \\
\hline 2013-07 & 4.326 & -4.129 & 8.455 & 5.180 & 1.6324 & 0.1034 \\
\hline 2014-07 & 6.838 & -5.264 & 12.101 & 6.653 & 1.8189 & 0.0697 \\
\hline 2015-07 & 7.811 & -3.339 & 11.150 & 6.523 & 1.7091 & 0.0882 \\
\hline
\end{tabular}

Source: own calculation

Table 7: ATT, DID and OLS of long-term profitability (\%) (to be continued). 


\begin{tabular}{|c|c|c|c|c|c|c|}
\hline OLS & Coef. & Robust SE & $\mathrm{t}$ & $\mathrm{p}$-value & \multicolumn{2}{|c|}{$95 \%$ Conf. Interval } \\
\hline Const. & 17.542 & 0.123 & 142.860 & 0.000 & 17.301 & 17.783 \\
\hline Lag0 & 1.690 & 0.977 & 1.730 & 0.084 & -0.231 & 3.611 \\
\hline Const. & 17.734 & 0.101 & 174.860 & 0.000 & 17.535 & 17.934 \\
\hline Lag1 & 0.972 & 0.896 & 1.080 & 0.279 & -0.790 & 2.734 \\
\hline Const. & 17.774 & 0.090 & 197.750 & 0.000 & 17.597 & 17.951 \\
\hline Lag2 & 1.540 & 0.793 & 1.940 & 0.053 & -0.018 & 3.099 \\
\hline Wald test & $\mathrm{F}$ & $\mathrm{p}$-value & corr(ui, Xb) & sigma_u & sigma_e & rho \\
\hline Lag0 & 2.990 & 0.085 & 0.075 & 49.328 & 28.228 & 0.753 \\
\hline Lag1 & 1.180 & 0.279 & 0.074 & 52.354 & 26.925 & 0.791 \\
\hline Lag2 & 3.780 & 0.053 & 0.074 & 55.699 & 24.979 & 0.833 \\
\hline
\end{tabular}

Source: own calculation

Table 7: ATT, DID and OLS of long-term profitability (\%) (continuation).

in the form of ROA, ROE or ROI. They revealed significant positive effects of investment support on profitability (Bernini and Pellegrini, 2011; Spicka et al., 2017).

Table 8 describes the development of labour productivity as measured by value added to labour cost.

From 2007-15, there were not any significant differences for average labour costs between participants and the control group in absolute values or in difference-in-difference approach. Thus, there is no effect of investment subsidies on labour productivity, which is a strategic goal of development programmes aimed at innovation and the modernization of manufacturing facilities. When considering time lag, there were not any significant lagged effects of investment support on labour productivity. This is a particularly important finding for policy makers. Despite the finding that innovator's size and employment grow faster than the companies with a low innovation, which is in line with previous findings (Freel, 2000), there was not any significant change in labour productivity for the treated companies. Our finding is in contrast with previous findings from the agricultural sector (Ratinger et al., 2013), but it supports findings from the meat processing industry (Spicka et al., 2017). Decramer and Vanormelingen (2016) found that the effect of the subsidies on the growth of the receiving firms was rather limited. Only for the very small firms was there a positive effect on investment, employment, sales, value added and productivity. For larger firms, they did not find any effect. In our sample, there were not any very small firms. Therefore, our results confirm previous findings.

On the one hand, modernization and innovation should improve labour productivity due to the implementation of more efficient technologies (Harrison et al., 2014). In the Czech Republic, empirical research indicated laboursaving for the capital- and material-intensive behaviours of the food processing companies (Rudinskaya, 2017). It is particularly important since there has been a lack of blue-collar workers in Central European countries (Svejnar, 1995). However, there is pressure on keeping employment in the countryside, which is a strategic focus of the Rural Development Programme. No significant effects of investment support on labour productivity in the Czech Food industry could be caused by poor selection criteria of project applications from 2007-2013. Evaluation put little stress on the efficiency and productivity of investment projects. In the new programming period since 2014, a new evaluation system has been implemented that is based on cost-effectiveness analysis and financial planning.

Direct cost efficiency is another key indicator for impact assessment. It describes the relationship between sales of products and intermediate consumption (cost of material, energy, services). Table 9 provides information regarding ATT, DID and lagged effects. A lower indicator denotes improved direct cost efficiency.

Participating companies had improved average direct cost efficiency more than nonparticipants from 2007-2015. However, there was a significant difference for only a few years. This indicates that participants were more efficient concerning relationships between direct cost and sales than nonparticipants. A pooled regression revealed positive effects for investment support on direct cost efficiency in the year of subsidy and one year after launching the investment project. Nevertheless, the effects are significant only at $\alpha=0.1$. 
Dynamic Effects of Public Investment Support in the Food and Beverage Industries

\begin{tabular}{|c|c|c|c|c|c|c|}
\hline Year & Participants & Control & ATT & SE & $\mathrm{t}$ & p-value \\
\hline 2007 & 1.732 & 1.583 & 0.149 & 0.170 & 0.8767 & 0.3811 \\
\hline 2008 & 1.568 & 1.401 & 0.166 & 0.123 & 1.3549 & 0.1762 \\
\hline 2009 & 1.678 & 1.542 & 0.137 & 0.128 & 1.0683 & 0.2860 \\
\hline 2010 & 1.461 & 1.563 & -0.103 & 0.213 & -0.4829 & 0.6295 \\
\hline 2011 & 1.576 & 1.561 & 0.015 & 0.122 & 0.1216 & 0.9033 \\
\hline 2012 & 1.469 & 1.463 & 0.006 & 0.093 & 0.0609 & 0.9515 \\
\hline 2013 & 1.598 & 1.532 & 0.066 & 0.096 & 0.6793 & 0.4973 \\
\hline 2014 & 1.676 & 1.600 & 0.076 & 0.093 & 0.8168 & 0.4145 \\
\hline 2015 & 1.567 & 1.615 & -0.048 & 0.160 & -0.2999 & 0.7644 \\
\hline DID & Participants & Control & ATT & SE & $\mathrm{t}$ & $\mathrm{p}$-value \\
\hline 2008-07 & -0.164 & -0.181 & 0.017 & 0.138 & 0.1230 & 0.9022 \\
\hline 2009-07 & -0.053 & -0.041 & -0.012 & 0.169 & -0.0738 & 0.9412 \\
\hline $2010-07$ & -0.271 & -0.019 & -0.252 & 0.215 & -1.1707 & 0.2424 \\
\hline 2011-07 & -0.156 & -0.022 & -0.135 & 0.172 & -0.7827 & 0.4342 \\
\hline $2012-07$ & -0.263 & -0.120 & -0.144 & 0.158 & -0.9098 & 0.3635 \\
\hline 2013-07 & -0.134 & -0.050 & -0.084 & 0.161 & -0.5215 & 0.6023 \\
\hline 2014-07 & -0.056 & 0.017 & -0.073 & 0.160 & -0.4560 & 0.6487 \\
\hline 2015-07 & -0.164 & 0.033 & -0.197 & 0.210 & -0.9382 & 0.3487 \\
\hline OLS & Coef. & Robust SE & $\mathrm{t}$ & p-value & $95 \%$ Con & f. Interval \\
\hline Const. & 1.560 & 0.006 & 243.650 & 0.000 & 1.547 & 1.572 \\
\hline Lag0 & 0.049 & 0.051 & 0.960 & 0.338 & -0.051 & 0.149 \\
\hline Const. & 1.558 & 0.006 & 272.140 & 0.000 & 1.546 & 1.569 \\
\hline Lag1 & -0.028 & 0.051 & -0.550 & 0.579 & -0.127 & 0.071 \\
\hline Const. & 1.560 & 0.007 & 239.530 & 0.000 & 1.547 & 1.573 \\
\hline Lag2 & 0.040 & 0.057 & 0.700 & 0.485 & -0.073 & 0.153 \\
\hline Wald test & $\mathrm{F}$ & $p$-value & corr(ui, $\mathrm{Xb}$ ) & sigma_u & sigma_e & rho \\
\hline Lag0 & 0.920 & 0.338 & 0.065 & 1.023 & 1.023 & 0.500 \\
\hline Lag1 & 0.310 & 0.579 & -0.083 & 1.034 & 0.946 & 0.544 \\
\hline Lag2 & 0.490 & 0.485 & 0.067 & 1.057 & 0.951 & 0.552 \\
\hline
\end{tabular}

Source: own calculation

Table 8: ATT, DID and OLS of labour productivity (x).

\begin{tabular}{|c|c|c|c|c|c|c|}
\hline Year & Participants & Control & ATT & SE & $t$ & $\mathrm{p}$-value \\
\hline 2007 & 1.622 & 7.264 & -5.642 & 2.550 & -2.2123 & 0.0275 \\
\hline 2008 & 1.702 & 49.315 & -47.613 & 35.717 & -1.3331 & 0.1833 \\
\hline 2009 & 1.058 & 14.317 & -13.258 & 9.777 & -1.3561 & 0.1758 \\
\hline 2010 & 1.098 & 2.792 & -1.693 & 0.841 & -2.0141 & $\overline{0.0446}$ \\
\hline 2011 & 0.880 & 2.084 & -1.204 & 0.486 & -2.4751 & 0.0137 \\
\hline 2012 & 0.909 & 3.004 & -2.095 & 0.837 & -2.5036 & 0.0127 \\
\hline 2013 & 0.901 & 2.664 & -1.764 & 0.958 & -1.8421 & 0.0662 \\
\hline 2014 & 0.869 & 4.989 & -4.120 & 1.736 & -2.3732 & 0.0181 \\
\hline 2015 & 1.016 & 5.598 & -4.582 & 2.443 & -1.8757 & 0.0614 \\
\hline DID & Participants & Control & ATT & SE & $\mathrm{t}$ & $\mathrm{p}$-value \\
\hline 2008-07 & 0.080 & 42.051 & -41.971 & 34.365 & -1.2213 & 0.2227 \\
\hline 2009-07 & -0.563 & 7.052 & -7.616 & 9.176 & \begin{tabular}{l|l|}
-0.8300 \\
\end{tabular} & 0.4070 \\
\hline $2010-07$ & -0.524 & -4.472 & 3.949 & 2.348 & 1.6820 & 0.0933 \\
\hline 2011-07 & -0.742 & -5.180 & 4.438 & 2.326 & 1.9083 & 0.0570 \\
\hline 2012-07 & -0.713 & -4.260 & 3.547 & 2.374 & 1.4942 & 0.1359 \\
\hline 2013-07 & -0.721 & -4.600 & 3.878 & 2.006 & 1.9333 & 0.0539 \\
\hline $2014-07$ & -0.753 & -2.275 & 1.522 & 2.088 & \begin{tabular}{l|}
0.7289 \\
\end{tabular} & 0.4665 \\
\hline $2015-07$ & -0.606 & -1.667 & 1.061 & 2.150 & 0.4934 & 0.6220 \\
\hline
\end{tabular}

Source: own calculation

Table 9: ATT, DID and OLS of direct cost efficiency (x) (to be continued) 
Dynamic Effects of Public Investment Support in the Food and Beverage Industries

\begin{tabular}{|c|c|c|c|c|c|c|}
\hline OLS & Coef. & Robust SE & $\mathrm{t}$ & $\mathrm{p}$-value & $95 \%$ Cor & f. Interval \\
\hline Const. & 5.719 & 0.025 & 226.340 & 0.000 & 5.669 & 5.769 \\
\hline Lag0 & -0.380 & 0.201 & -1.890 & 0.059 & -0.775 & 0.015 \\
\hline Const. & 5.841 & 0.010 & 598.110 & 0.000 & 5.822 & 5.861 \\
\hline Lag1 & -0.147 & 0.086 & -1.700 & 0.090 & -0.316 & 0.023 \\
\hline Const. & 3.015 & 0.005 & 612.420 & 0.000 & 3.005 & 3.025 \\
\hline Lag2 & -0.020 & 0.043 & -0.460 & 0.644 & -0.105 & 0.065 \\
\hline Wald test & $\mathrm{F}$ & $\mathrm{p}$-value & $\operatorname{corr}(\mathrm{ui}, \mathrm{Xb})$ & sigma_u & sigma_e & rho \\
\hline Lag0 & 3.570 & 0.060 & 0.037 & 45.839 & 124.841 & 0.119 \\
\hline Lag1 & 2.890 & 0.090 & 0.035 & 49.201 & 132.858 & 0.121 \\
\hline Lag2 & 0.210 & 0.644 & 0.038 & 20.195 & 37.016 & 0.229 \\
\hline
\end{tabular}

Source: own calculation

Table 9: ATT, DID and OLS of direct cost efficiency (continuation).

These results correspond with previous findings from the agricultural sector (Medonos et al., 2012; Ratinger et al., 2013; Spicka et al., 2017). Uncovering positive effects for investment support on direct cost efficiency confirms the purpose of investment support as an important measurement for improving material and energy efficiency of participants.

\section{Conclusion}

The article focused on impact evaluation of investment support on selected important economic indicators using statistical and econometric methods. The case study of the Czech food industry from 2007-2015 noted some interesting findings that are important for policy makers and other stakeholders (managers, investors).

According to the policy guidelines, investment support should enhance viability and competitiveness and promote resource efficiency for supported enterprises. The food industry is a suitable branch for the case study because it has been heavily supported by European and national funds for a long time. The article partially confirmed previous studies but revealed new dynamic effects of investment support from three complementary grant programmes (the Rural Development Programme, a national subsidy programme and the Operational Programme Enterprise and Innovation). Supported companies were compared with similar non-treated companies from the same branches of the food and beverage industry.

If we generalize our findings, supported companies (participants) have higher investment activity than nonparticipants. Investment support increases the amount of fixed assets and size of participants.
Alternatively, nonparticipants invest enough to cover the depreciation of fixed assets and do not develop themselves. However, the turnover of fixed assets did not significantly improve after completion and launching the investment. This means that participants are not able to generate additional sales from new fixed assets to improve productivity. Finally, there could be another negative effect. It was revealed that nonparticipants that do not develop their business and investment support could have a crowding out effect for companies that have not received investment support, which corresponds to recent studies.

Second, investment support changes the capital structure of participants towards increased usage of bank loans and a growing credit debt ratio. This is particularly important for the next programming period of $2021+$ that will be more focused on financial instruments, which will play an important role in the achievement of Cohesion Policy objectives. Such instruments may take the form of equity or quasi-equity investments, loans or guarantees, or other risk sharing instruments. Where appropriate, they may be combined with grants.

Concerning the impact of investment support on profitability and productivity, empirical research showed only positive effects on longterm profitability at the 0.1 significance level for the year of support and two years after support. A positive effect for investment support on longterm profitability is good news for management of supported companies and policy makers. Long-term profitability has been one of the key selection criteria in the Czech RDP. However, no effect of investment support on labour productivity is a very unfavourable finding since increasing labour productivity is key goal of all investigated development programmes. 
In the previous programming period from 20072013, the Ministry of Agriculture did not require proper ex-ante evaluation of project applications. Neither financial plans nor cost benefit analyses were included in project applications. Project selection was based on a verbal description of project, features of the applicant and the rate of investment subsidy (from $40 \%$ to $50 \%$ ). In the current programming period, selection criteria have been improved to include costefficiency analysis and financial planning.

Finally, this research revealed positive dynamic effects for investment support on direct cost efficiency, which supports ongoing efforts to improve resource efficiency. The current RDP puts more emphasis on material and energy efficiency and related environmental effects.

\section{Acknowledgements}

This study was funded by the institutional support for long-term conceptual development of the research organization University of Economics, Prague (research project "The Impact of Support for Public Investment Projects on the Gross Added Value of Supported Enterprises", No. F3/46/2017) provided by the Ministry of Education, Youth and Sports.

Corresponding authors:

doc. Ing. Jindřich Špička, Ph.D.

Department of Strategy, Faculty of Business Administration, University of Economics Prague

W. Churchill Sq. 4, 13067 Prague 2, Czech Republic

Phone: +420224098351,E-mail: jindrich.spicka@vse.cz

\section{References}

[1] Abadie, A. (2005) "Semiparametric Difference-in-Differences Estimators", The Review of Economic Studies, Vol. 72, No. 1, pp. 1-19. ISSN 0034-6527.

[2] Abadie, A. and Imbens, G.W. (2006) "Large Sample Properties of Matching Estimators for Average Treatment Effects", Econometrica, Vol. 74, No. 1, pp. 235-267. ISSN 0012-9682. DOI 10.1111/j.1468-0262.2006.00655.x.

[3] Allison, P. D. (2009) "Fixed Effects Regression Models", Quantitative Applications in the Social Sciences, 07-160, SAGE, London, ISBN 978-07-619-2497-5.

[4] Angrist, J. D., Imbens, G. W. and Rubin, D. B. (1996) "Identification of Causal Effects Using Instrumental Variables", Journal of the American Statistical Association, Vol. 91, No. 434, p. 444. ISSN 0162-1459. DOI 10.2307/2291629.

[5] Arellano, M. and Bond, S. (1998) "Dynamic Panel Data Estimation Using DPD98 For Gauss: A Guide for Users", [Online]. Available: ftp://ttp.cemfi.es/pdf/papers/ma/dpd98.pdf [Accessed: 5 Jan. 2018].

[6] Bartova, L. and Hornakova, J. (2016) "Farm Investment Support in the Slovak Republic", in Smutka, L., Benda, P., Cermakova, H., Domeova, L., Fejfarova, M., Halova, P., Havlicek, Z., Havlikova, M., Havranek, M., Hlavsa, T., Lorinczova, E., Lostak, M., Mach, J., Maly, M., Moravec, L., Pilar, L., Prasilova, M., Prochazkova, R., Rojk, S., Rumankova, L., Slaboch, J., Kristkova, Z., Starova, M., Sanova, P., Simek, P., Tyrychtr, J., Ulman, M., Urbancova, H., Zagata, L. and Zakova Kroupova, Z. (Eds.), Agrarian Perspectives XXV. - Global and European Challenges For Food Production, Agribusiness and the Rural Economy: Proceedings of the $25^{\text {th }}$ International Scientific Conference on Agrarian Perspectives, Prague, Czech Republic, September 14-16, Czech University of Life Sciences, Faculty of Economics and Management, Prague, pp. 34-40. ISBN 978-80-213-2670-5.

[7] Bergemann, A., Fitzenberger, B. and Speckesser, S. (2009) "Evaluating the Dynamic Employment Effects of Training Programs in East Germany Using Conditional Difference-inDifferences", Journal of Applied Econometrics, Vol. 24, No. 5, pp. 797-823. ISSN 0883-7252. DOI 10.1002/jae.1054.

[8] Bernini, C. and Pellegrini, G. (2011) "How Are Growth and Productivity in Private Firms Affected by Public Subsidy? Evidence from a Regional Policy", Regional Science and Urban Economics, Vol. 41, No. 3, pp. 253-265. ISSN 0166-0462. DOI 10.1016/j.regsciurbeco.2011.01.005. 
[9] Bertrand, M., Duflo, E. and Mullainathan, S. (2004) "How Much Should We Trust DifferencesIn-Differences Estimates?", The Quarterly Journal of Economics, Vol. 119, No. 1, pp. 249-275. ISSN 0033-5533. DOI 10.1162/003355304772839588.

[10] Bia, M. and Mattei, A. (2012) "Assessing the Effect of The Amount of Financial Aids to Piedmont Firms Using the Generalized Propensity Score”, Statistical Methods \& Applications, Vol. 21, No. 4, pp. 485-516. ISSN 1618-2510. DOI 10.1007/s10260-012-0193-4.

[11] Bozik, M. (2011) "Hodnotenie efektov opatrení podpory investícií Programu rovoje vidieka 2007-2013 na úrovni fariem", Economics in Agriculture, Vol. 11, No. 1, pp. 58-71. ISSN 1338-6336.

[12] Caliendo, M. and Kopeinig, S. (2008) "Some Practical Guidance for the Implementation of Propensity Score Matching", Journal of Economic Surveys, Vol. 22, No. 1, pp. 31-72. ISSN 0950-0804. DOI 10.1111/j.1467-6419.2007.00527.x.

[13] Cerqua, A. and Pellegrini, G. (2014) "Do Subsidies to Private Capital Boost Firms' Growth? A Multiple Regression Discontinuity Design Approach", Journal of Public Economics, Vol. 109, No. January 2014, pp. 114-126. ISSN 0047-2727. DOI 10.1016/j.jpubeco.2013.11.005.

[14] Ciaian, P., Kancs, D. and Michalek, J. (2015) "Investment Crowding-Out. Firm-Level Evidence from Germany", LICOS Discussion Paper, No. 370/2015. [Online]. Available: https://ssrn.com/ abstract=2634922. DOI 10.2139/ssrn.2634922.

[15] Decramer, S. and Vanormelingen, S. (2016) "The Effectiveness of Investment Subsidies. Evidence from a Regression Discontinuity Design", Small Business Economics, Vol. 47, No. 4, pp. 1007-1032. ISSN 0921-898X. DOI 10.1007/s11187-016-9749-2.

[16] Duflo, E., Glennerster, R. and Kremer, M. (2008) "Chapter 61 Using Randomization in Development Economics Research: A Toolkit", in Schultz, T. P. and Strauss, J. (Eds.) "Handbook of development economics", Handbooks in Economics, Vol. 4, North Holland, Amsterdam, London, pp. 3895-3962. ISSN 0169-7218.

[17] European Commission - Directorate-General for Agriculture and Rural Development (2014) "Investment Support under Rural Development Policy: Contract 30-CE-0609852/00-41", Final Report, Publications Office of the European Union, Luxembourg.

[18] European Commission - Directorate-General for Agriculture and Rural Development. (2016) "Guidelines: Assessment of RDP Results: How to Prepare for Reporting on Evaluation in 2017: Annex 11 - Fiches For Answering Common Evaluation Questions For Rural Development Programmes 2014-2020", Brussels.

[19] Freel, M. S. (2000) "Do Small Innovating Firms Outperform Non-Innovators?", Small Business Economics, Vol. 14, No. 3, pp. 195-210. ISSN 0921-898X. DOI 10.1023/A:1008100206266.

[20] Gilligan, D. O. and Hoddinott, J. (2007) "Is There Persistence in the Impact of Emergency Food Aid? Evidence on Consumption, Food Security, and Assets in Rural Ethiopia", American Journal of Agricultural Economics, Vol. 89, No. 2, pp. 225-242. ISSN 0002-9092. DOI 10.1111/j.1467-8276.2007.00992.x.

[21] Greene, W. H. (2012), "Econometric Analysis, Pearson Series in Economics", $7^{\text {th }}$ ed., International ed., Pearson Education, Boston.

[22] Gu, X. S. and Rosenbaum, P. R. (1993) "Comparison of Multivariate Matching Methods. Structures, Distances, and Algorithms", Journal of Computational and Graphical Statistics, Vol. 2, No. 4, p. 405. ISSN 1061-8600. DOI 10.2307/1390693.

[23] Hahn, J., Todd, P. and Klaauw, W. (2001) "Identification and Estimation of Treatment Effects with a Regression-Discontinuity Design", Econometrica, Vol. 69, No. 1, pp. 201-209. ISSN 0012-9682. DOI 10.1111/1468-0262.00183.

[24] Harris, R. and Trainor, M. (2005) "Capital Subsidies and their Impact on Total Factor Productivity. Firm-Level Evidence from Northern Ireland”, Journal of Regional Science, Vol. 45, No. 1, pp. 49-74. ISSN 0022-4146. DOI 10.1111/j.0022-4146.2005.00364.x. 
[25] Harrison, R., Jaumandreu, J., Mairesse, J. and Peters, B. (2014) "Does Innovation Stimulate Employment? A Firm-Level Analysis Using Comparable Micro-Data from Four European Countries", International Journal of Industrial Organization, Vol. 35, No. July 2014, pp. 29-43. ISSN 0167-7187. DOI 10.1016/j.jindorg.2014.06.001.

[26] Heckman, J., Ichimura, H., Smith, J. and Todd, P. (1998) "Characterizing Selection Bias Using Experimental Data”, Econometrica, Vol. 66, No. 5, p. 1017. ISSN 0012-9682. DOI 10.2307/2999630.

[27] Ho, D., Imai, K., King, G. and Stuart, E. (2007) "Matching as Nonparametric Preprocessing for Reducing Model Dependence in Parametric Causal Inference", Political Analysis, Vol. 15, No. 3, p. 199-236. ISSN 1047-1987. DOI 10.1093/pan/mpl013.

[28] Khandker, S. R., Koolwal, G. B. and Samad, H. A. (2010) "Handbook on impact Evaluation: Quantitative Methods and Practices", World Bank, Washington, D.C. ISBN 978-0-81213-8028-4.

[29] Kirchweger, S. and Kantelhardt, J. (2015) "The Dynamic Effects of Government-Supported FarmInvestment Activities on Structural Change in Austrian Agriculture", Land Use Policy, Vol. 48, No. November 2015, pp. 73-93. ISSN 0264-8377. DOI 10.1016/j.landusepol.2015.05.005.

[30] Kirchweger, S., Kantelhardt, J. and Leisch, F. (2015) "Impacts of The Government-Supported Investments on The Economic Farm Performance in Austria", Agricultural Economics (Zemédělská ekonomika), Vol. 61, No. 8, pp. 343-355. ISSN 0139-570X. DOI 10.17221/250/2014-AGRICECON.

[31] Krejcie, R. V. and Morgan, D. W. (1970) "Determining Sample Size for Research Activities", Educational and Psychological Measurement, Vol. 30, No. 3, pp. 607-610. ISSN 0013-1644. DOI 10.1177/001316447003000308.

[32] Lee, D. S. and Lemieux, T. (2010) "Regression Discontinuity Designs in Economics", Journal of Economic Literature, Vol. 48, No. 2, pp. 281-355. ISSN 0022-0515. DOI 10.1257/jel.48.2.281.

[33] Medonos, T., Ratinger, T., Hruska, M. and Spicka, J. (2012) "The Assessment of the Effects of Investment Support Measures of the Rural Development Programmes: the Case of the Czech Republic", Agris on-line Papers in Economics and Informatics, Vol. 4, No. 4, pp. 35-48. ISSN 1804-1930.

[34] Michalek, J. (2012) "Counterfactual impact evaluation of EU rural development programmes: Propensity score matching methodology applied to selected EU Member States, Volume 1: A microlevel approach”, EUR (Luxembourg. Online), Vol. 25421, Publications Office; FAO, Luxembourg, Rome.

[35] Ministry of Agriculture, MoA (2008) "Rural Development Programme of the Czech Republic for 2007 - 2013”, Prague, Ministry of Agriculture.

[36] Ministry of Industry and Trade, MoIT. (2007) “Operational Programme Enterprise and Innovation", Prague, Ministry of Industry and Trade.

[37] Naglova, Z., Spicka, J. and Gurtler, M. (2016) "Evaluation of Effects of Investment Support in the Czech Dairy Industry", Acta Universitatis Agriculturae et Silviculturae Mendelianae Brunensis, Vol. 64, No. 4, pp. 1345-1351. ISSN 1211-8516. DOI 10.11118/actaun201664041345.

[38] Petrick, M. and Zier, P. (2011) "Regional Employment Impacts of Common Agricultural Policy Measures in Eastern Germany. A Difference-in-Differences Approach", Agricultural Economics, Vol. 42, No. 2, pp. 183-193. ISSN 0169-5150. DOI 10.1111/j.1574-0862.2010.00509.x.

[39] Pufahl, A. and Weiss, C. R. (2009) "Evaluating the effects of farm programmes. Results from propensity score matching", European Review of Agricultural Economics, Vol. 36, No. 1, pp. 79-101. ISSN 0165-1587. DOI 10.1093/erae/jbp001.

[40] Ratinger, T., Medonos, T. and Hruska, M. (2013) "An Assessment of the Differentiated Effects of the Investment Support to Agricultural Modernisation: the Case of the Czech Republic", Agris on-line Papers in Economics and Informatics, Vol. 5, No. 4, pp. 153-164. ISSN 1804-1930.

[41] Ravallion, M. (2005) "Evaluating Anti-Poverty Programs", The World Bank. 
[42] Rezbova, H. and Skubna, O. (2013) "Analysis of the Impact of Subsidies on Economic Performance of Agricultural Enterprises in the Czech Republic", in Smutka, L. and Zagata, L. (Eds.), Agrarian Perspectives XXII. - Development Trends In Agribusiness: Proceedings of the $22^{\text {th }}$ International Scientific Conference on Agrarian Perspectives, Prague, Czech Republic, September 17 - 18 , Czech University of Life Sciences, Faculty of Economics and Management, Prague, pp. 78-85. ISBN 978-80-213-2419-0.

[43] Rosenbaum, P. R. (1989) "Optimal Matching for Observational Studies”, Journal of the American Statistical Association, Vol. 84, No. 408, p. 1024. ISSN 0162-1459. DOI 10.2307/2290079.

[44] Rosenbaum, P. R. and Rubin, D. B. (1985) "Constructing a Control Group Using Multivariate Matched Sampling Methods That Incorporate the Propensity Score", The American Statistician, Vol. 39, No. 1, p. 33. ISSN 0003-1305. DOI 10.2307/2683903.

[45] Rudinskaya, T. (2017) "Heterogeneity and Efficiency of Food Processing Companies in the Czech Republic”, Agricultural Economics (Zemedelska ekonomika), Vol. 63, No. 9, pp. 411-420. ISSN 0139-570X. DOI 10.17221/1/2016-AGRICECON.

[46] Smith, J.A. and Todd, P. E. (2005) "Does Matching Overcome LaLonde's Critique of Nonexperimental Estimators?", Journal of Econometrics, Vol. 125, No. 1-2, pp. 305-353. ISSN 0304-4076. DOI 10.1016/j.jeconom.2004.04.011.

[47] Spicka, J., Naglova, Z. and Gurtler, M. (2017) "Effects of The Investment Support in the Czech Meat Processing Industry", Agricultural Economics (Zemedelska ekonomika), Vol. 63, No. 8, pp. 356-369. ISSN 0139-570X. DOI 10.17221/367/2015-AGRICECON.

[48] Spicka, J., Smutka, L. and Selby, R. (2016) "Recent Areas of Innovation Activities in the Czech Dairy Industry”, Agricultural Economics (Zemedelska ekonomika), Vol. 61, No. No. 6, pp. 249-264. ISSN 0139-570X. DOI 10.17221/128/2014-AGRICECON.

[49] Svejnar, J. (1995) "The Czech Republic and Economic Transition in Eastern Europe", San Diego, California, Academic Press, ISBN 0-12-678180-X.

[50] van der Klaauw, W. (2002) "Estimating the Effect of Financial Aid Offers on College Enrollment. A Regression-Discontinuity Approach”, International Economic Review, Vol. 43, No. 4, pp. 1249-1287. ISSN 0020-6598. DOI 10.1111/1468-2354.t01-1-00055.

[51] Wooldridge, J. M. (2016) "Introductory Econometrics: A Modern Approach", $6^{\text {th }}$ edition, Cengage Learning, Boston, MA. 


\section{Appendix}

\begin{tabular}{|l|l|l|c|}
\hline Factors & Indicators & \multicolumn{1}{|c|}{ Unit } & Cumulative Percent \\
\hline F1: Company's size & Total Assets & '000 CZK & 35.54 \\
\hline F2: Financial stability & Debt Coverage = Cash Flow / Debt & times & 43.61 \\
\hline F3: Trading goods & Cost of Goods Sold & '000 CZK & 49.16 \\
\hline F4: Intensity & $\begin{array}{l}\text { Asset Turnover = Sales of Goods and Products / Total } \\
\text { Assets }\end{array}$ & times & 53.82 \\
\hline F5: Liquidity & $\begin{array}{l}\text { Acid Test Ratio = (Current Assets - Inventory) / Current } \\
\text { Liabilities }\end{array}$ & times & 57.66 \\
\hline F6: Retained earnings & Retained earnings & '000 CZK & 61.29 \\
\hline F7: Use of bank loans & Bank loans & '000 CZK & 64.73 \\
\hline F8: Financial leverage & Debt Equity Ratio = (Debt / Equity) x 100 & 67.95 \\
\hline F9: Sales of long-term assets & Revenues from disposals of fixed assets and materials & '000 CZK & 71.04 \\
\hline F10: Capital structure & Debt Ratio = (Debt / Total Assets) x 100 & $\%$ & 73.99 \\
\hline $\begin{array}{l}\text { F11: Working capital } \\
\text { management }\end{array}$ & $\begin{array}{l}\text { Working Capital Ratio (WCR) = Net Working Capital / } \\
\text { Sales of Goods and Products x 100 }\end{array}$ & $\%$ & 76.62 \\
\hline F12: Financial earnings & Profit / loss from financial operations (transactions) & '000 CZK & 78.73 \\
\hline F13: Production margin & $\begin{array}{l}\text { Relative Gross Profit Margin = ((Sales of Products - Cost } \\
\text { of Products Sold) / Sales of Products) x 100 }\end{array}$ & $\%$ & 80.69 \\
\hline
\end{tabular}

Source: own calculation

Table A1: Results of the PCA.

\begin{tabular}{|c|c|c|c|c|c|c|c|}
\hline Variable & Coef. & Std. Err. & $\mathrm{z}$ & p-value & Odds Ratio & \multicolumn{2}{|c|}{ [95\% Conf. Interval] } \\
\hline Const. & 0.566 & 0.219 & 2.586 & 0.010 & 1.761 & 0.137 & 0.994 \\
\hline Bank loans & 0.000 & 0.000 & 2.955 & 0.003 & 1.000 & 0 & 0 \\
\hline Debt Ratio & -0.008 & 0.003 & -2.828 & 0.005 & 0.992 & -0.014 & -0.003 \\
\hline Liquidity & -0.095 & 0.045 & -2.138 & 0.033 & 0.909 & -0.183 & -0.008 \\
\hline Log Likelihood & -411.886 & \multirow{2}{*}{\multicolumn{6}{|c|}{$\mathrm{N}=620$}} \\
\hline Model R ${ }^{2}$ & 0.0305 & & & & & & \\
\hline
\end{tabular}

Source: own calculation

Table A2: Results of logit regression - selection of significant variables $(\mathrm{N}=620)$ 


\begin{tabular}{|c|c|c|c|c|c|c|}
\hline \multicolumn{7}{|c|}{ Group Comparison Report for Variable $=$ Logit(ps) } \\
\hline Group Type & Treated & $\mathbf{N}$ & Mean & SD & $\begin{array}{c}\text { Mean } \\
\text { Difference }\end{array}$ & $\begin{array}{c}\text { Standardized } \\
\text { Difference }(\%)\end{array}$ \\
\hline \multirow[t]{2}{*}{ Before Matching } & 1 & 271 & -0.1076 & 0.49 & & \\
\hline & 0 & 349 & 0.1167 & 0.78 & -0.2243 & $-34.39 \%$ \\
\hline \multirow[t]{2}{*}{ After Matching } & 1 & 206 & -0.0406 & 0.36 & & \\
\hline & 0 & 206 & 0.0352 & 0.3 & -0.0758 & $-22.93 \%$ \\
\hline \multicolumn{7}{|c|}{ Group Comparison Report for Variable $=$ Bank loans } \\
\hline Group Type & Treated & $\mathbf{N}$ & Mean & SD & $\begin{array}{c}\text { Mean } \\
\text { Difference }\end{array}$ & Standardized \\
\hline \multicolumn{7}{|l|}{ Difference $(\%)$} \\
\hline \multirow[t]{2}{*}{ Before Matching } & 1 & 271 & 49774.41 & 129402.5 & & \\
\hline & 0 & 349 & 19823.43 & 88391.27 & 29950.98 & $27.03 \%$ \\
\hline \multirow[t]{2}{*}{ After Matching } & 1 & 206 & 32889.38 & 79004.24 & & \\
\hline & 0 & 206 & 15123.61 & 44212.91 & 17765.77 & $27.75 \%$ \\
\hline \multicolumn{7}{|c|}{ Group Comparison Report for Variable = Liquidity (Acid Test Ratio) } \\
\hline Group Type & Treated & $\mathbf{N}$ & Mean & SD & $\begin{array}{c}\text { Mean } \\
\text { Difference }\end{array}$ & $\begin{array}{c}\text { Standardized } \\
\text { Difference }(\%)\end{array}$ \\
\hline \multirow[t]{2}{*}{ Before Matching } & 1 & 271 & 1.6603 & 1.74 & & \\
\hline & 0 & 349 & 2.2452 & 6.78 & -0.5849 & $-11.81 \%$ \\
\hline \multirow[t]{2}{*}{ After Matching } & 1 & 206 & 1.6393 & 1.79 & & \\
\hline & 0 & 206 & 1.5791 & 1.74 & 0.0603 & $3.41 \%$ \\
\hline \multicolumn{7}{|c|}{ Group Comparison Report for Variable = Debt Ratio $(\%)$} \\
\hline Group Type & Treated & $\mathbf{N}$ & Mean & SD & $\begin{array}{c}\text { Mean } \\
\text { Difference }\end{array}$ & $\begin{array}{l}\text { Standardized } \\
\text { Difference }(\%)\end{array}$ \\
\hline \multirow[t]{2}{*}{ Before Matching } & 1 & 271 & 59.6552 & 27.32 & & \\
\hline & 0 & 349 & 67.3433 & 53.41 & -7.6881 & $-18.12 \%$ \\
\hline \multirow[t]{2}{*}{ After Matching } & 1 & 206 & 60.7391 & 27.92 & & \\
\hline & 0 & 206 & 62.9961 & 35.71 & -2.257 & $-7.04 \%$ \\
\hline
\end{tabular}

Source: own calculation

Table A3: Results of PSM 